\title{
INFRARED SPECTROSCOPY AND MULTIVARIATE CALIBRATION FOR THE RAPID QUANTIFICATION OF FREE FATTY ACID CONTENT IN PANGASIUS HYPOPTHALMUS OIL
}

\author{
LISA ANDINA ${ }^{1 *}$, REVITA SAPUTRI ${ }^{1}$, ARISTHA NOVYRA PUTRI ${ }^{1}$, ABDUL ROHMAN $^{* *}$ \\ 1Department of Pharmacy, Sekolah Tinggi Ilmu Kesehatan Borneo Lestari, Banjarbaru, 70714 Indonesia, ${ }^{2}$ Faculty of Pharmacy, Gadjah \\ Mada University, Yogyakarta, 55281 Indonesia \\ Email: lisaandina@stikesborneolestari.ac.id
}

Received: 06 Aug 2018, Revised and Accepted: 21 Sep 2018

\section{ABSTRACT}

Objective: The objective of this study was to evaluate the capability of fourier transform infrared (FTIR) spectroscopy in combination with multivariate calibration for prediction of free fatty acids (FFA) in Pangasius hypopthalmus (P. hypopthalmus) oil.

Methods: FFA content in P. hypopthalmus oil was determined by attenuated total reflectance-FTIR spectroscopy. P. hypopthalmus oil derived from Pangasius's meat (MP), and Pangasius's liver and fat (LFP) were subjected to heat treatments. Determination of FFA content in P. hypopthalmus oil's was performed by gas chromatography-flame ionization detector.

Results: Oleic acid was found to be the main fatty acid component in P. hypopthalmus oil. FTIR spectra of $P$. hypopthalmus oil has 3 main peaks, C-H bonds of cis-form of fatty acid showed the stretching vibration, symmetric and asymmetric vibrations of the C- $\mathrm{H}_{2}$ and $\mathrm{C}-\mathrm{H}_{3}$ aliphatic group and vibrations of the carbonyl $(\mathrm{C}=0)$ ester derived from the oil triacylglycerols. Principal component regression (PCR) model showed a better performance than the partial least square (PLS) model. PCR at wavenumbers of 1200-1000 $\mathrm{cm}^{-1}$ with first derivative treatment was chosen for FFA prediction, which resulted in a coefficient of determination $\left(\mathrm{R}^{2}\right)$ value of 0.9417 , root means square error of calibration (RMSEC) of $0.725 \%$, and root mean square error of prediction (RMSEP) value of $2.40 \%$, respectively.

Conclusion: FTIR spectroscopy combined with PCR can be used as an alternative method for analysis of fatty acid contents.

Keywords: Pangasius hypopthalmus oil, FTIR spectroscopy, Free fatty acid, Principal component regression

(C) 2018 The Authors. Published by Innovare Academic Sciences Pvt Ltd. This is an open access article under the CC BY license (http://creativecommons.org/licenses/by/4.0/) DOI: http://dx.doi.org/10.22159/ijap.2018v10i6.28969

\section{INTRODUCTION}

Pangasius hypopthalmus (fig. 1) is one of the widely consumed fish commodities in Indonesia which it's production has increased significantly over the last few years. In 2004 the production of $P$. hypopthalmus amounted to 23.962 tons and increased to 52.470 tons in 2008. P. hypopthalmus is also one of a very popular freshwater fish that consumed worldwide [1]. Based on Hwang et al. $P$. hypopthalmus abdominal part including the gastrointestinal tract, liver, gallbladder, and abdominal fat were the potential source of high omega 3 fat [2]. Panagan et al. [3] reported that omega 3 acids content in P. hypopthalmus oil ranged from 1.16 to $12.44 \%$. The production of $P$. hypopthalmus in South Kalimantan in 2014 was reached to 70.000 tons per year [4]. Currently, the most widely cultivated catfish species in Indonesia are P. djambal (jambal catfish) and $P$. hypophthalmus (Siamese catfish).

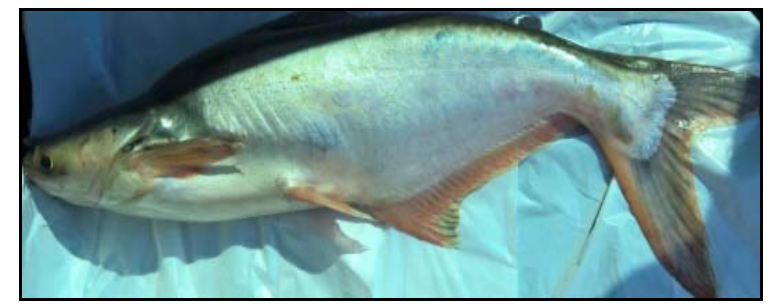

Fig. 1: Pangasius hypopthalmus

Free fatty acid content (FFA) is one of the parameters that can be used to represent the quality of an edible oil. According to the standard method, FFA is determined by titration method. This procedure required a large number of a chemical solvent which has an adverse impact on the environment. It also required trained laboratory assistant and long processing time, which is laborious and time-consuming. Fourier transform infrared (FTIR) combined with chemometrics are reported to be the alternative method for the determination of oil quality and stability such as acid value $[5,6]$, free fatty acid value [5], saponification value $[7,8]$, iodine value [7, 9], peroxide value [10,11], and anisidine value [12, 13]. Besides, FTIR was also successfully used as an alternative for a quantitative method for pharmaceuticals $[14,15]$. It was found to be rapid, easy technique, and in contrary to the standard method it doesn't require a large amount of sample and chemical solvent. Which have made this method less expensive and environmentally friendly.

This study was intended to develop a quantitative method for the FFA content in P. hypopthalmus oil. The developed model would be compared to the standard titration method using chemometric with a set of validation data.

\section{MATERIALS AND METHODS}

\section{P. hypopthalmus oil extraction}

P. hypopthalmus was divided into meat, liver, and abdominal fat for further processing by dry rendering. Each part was heated to a temperature of $60^{\circ} \mathrm{C}$ until the oil stop to comes out and then filtered. The extraction products were labeled as Pangasius's meat (MP) and Pangasius's liver and fat (LFP).

\section{Fatty acid determination}

The profiles of fatty acids in P. hypopthalmus oil were determined by gas chromatography-flame ionization detector (GC-FID) according to Rohman and Che Man method [16]. Approximately $50.0 \mathrm{mg}$ of oil was dissolved in $0.8 \mathrm{ml}$ of n-hexane, added with $0.2 \mathrm{ml}$ of sodium methoxide (1 M), and then shook using vortex for 1 minute. Glycerol was precipitated by addition of saturated sodium chloride ( 5 drops) to the mixture, then mixed for 15 seconds. A- $1 \mu \mathrm{L}$ supernatant was injected into GC using condition as follows, column: RTX-5 capillary column (thickness: $0.2 \mu \mathrm{m}$, internal diameter $0.25 \mathrm{~mm}$, length: 30 $\mathrm{m})$; oven: $50{ }^{\circ} \mathrm{C}(1 \mathrm{~min})$ increased to $240{ }^{\circ} \mathrm{C}$; detector: flame ionization detector; and carrier gas: $\mathrm{N}_{2}(6.8 \mathrm{ml} / \mathrm{min})$. 


\section{FTIR measurement}

$P$. hypopthalmus oil was measured by FTIR spectrophotometer Nicolet 6700 with deuterated triglycine sulphate (DTGS) as a detector and linked with OMNIC software (version 7.0 thermo nicolet). The sample was placed on the attenuated total reflectance (ATR) crystal, and the measurements were performed on 32 scans, a resolution of $4 \mathrm{~cm}^{-1}$ and at a controlled temperature $\left(20{ }^{\circ} \mathrm{C}\right)$. All spectra were recorded in triplicate measurement at wavenumbers of 4000-650 $\mathrm{cm}^{-1}$ using absorbance mode.

\section{Free fatty acid content (FFA) determination}

FFA was determined by the standard titration method. FTIR method was developed by modification of Andina et al. [11, 13] for the determination of $P$. hypopthalmus oil's FFA. Approximately $150 \mathrm{ml}$ of samples in $250 \mathrm{ml}$ beaker glass $\left(\right.$ Pyrex $^{\circledR}$ ) were subjected to heat treatment at $150^{\circ} \mathrm{C}$ for $15,30,60,120,360,480$ and $600 \mathrm{~min}$.
Samples were then measured by ATR-FTIR with the same condition as the previous measurement. Partial least squares regression (PLS) and principal component regression (PCR) were carried out using the software of TQ analyst 9 .

\section{RESULTS AND DISCUSSION}

The result of fatty acid determination can be seen in table 1. Oleic acid $(37.36 \%)$ was found to be the main fatty acid. Different habitat water temperature affects the fatty acid profile of fish. Water temperature usually affects polar lipids, but it also increased the changes from unsaturated to the saturated fatty acid ratio in fish [17-20]. The member of the short-chain group C4-C14 of saturated fatty acids was present in large amount consist of butyric, lauric, and myristic acids. The number of short chain fatty acids affect the consistency of $P$. hypopthalmus oil, it appears partly solidified at room temperature, respectively. Fatty acids with the short-chain of carbon were also found in coconut oil, palm kernel oil, and milk fats [21].

Table 1: Fatty acid profiles in $P$. hypopthalmus oil

\begin{tabular}{|c|c|c|}
\hline Fatty acid classification & Fatty acid & $(\%)$ \\
\hline \multirow[t]{5}{*}{ Saturated fatty acid (SFA) } & Butyric C4:0 & 13.23 \\
\hline & Lauric C12:0 & 0.58 \\
\hline & Myristic C14:0 & 3.85 \\
\hline & Palmitic C16:0 & 26.08 \\
\hline & $\Sigma$ SFA & 43.74 \\
\hline \multirow[t]{3}{*}{ Mono unsaturated fatty acid (MUFA) } & Elaidic C18:1 $9 t(n-9)$ & 6.79 \\
\hline & Oleic C18:1 (n-9) & 37.36 \\
\hline & $\Sigma$ MUFA & 44.15 \\
\hline \multirow[t]{2}{*}{ Poly unsaturated fatty acid (PUFA) } & Linoleic C18:2 (n-6) & 12.09 \\
\hline & $\Sigma$ PUFA & 12.09 \\
\hline
\end{tabular}

FTIR spectra of $P$. hypopthalmus oil have similarities with other edible oils. As shown in fig. 2 the FTIR spectrum of $P$. hypopthalmus oil has 3 main peaks. A peak at $3007.31 \mathrm{~cm}^{-1}$ was derived from a stretching vibration of the carbon and hydrogen bonds in cis double bond [22-26], due to the presence of cis-oleic in P. hypopthalmus oil. There peaks at 2921 and $2852 \mathrm{~cm}^{-1}$ are corresponding to the symmetric and asymmetric stretching vibrations of the carbon aliphatic group [22, 27]. The presence of the carbonyl $(\mathrm{C}=0)$ ester from the oil triacylglycerol vibrations shown at $1743 \mathrm{~cm}^{-1}$ [28]. The strong intensity due to the big difference of carbon and hydrogen atoms electro-negativity [22, 24, 26].
The fingerprint area of $P$. hypopthalmus oil spectra region was found between 721-1464 $\mathrm{cm}^{-1}$, respectively. Peaks appear at 1464, and 1377 $\mathrm{cm}^{-1}$ also derived from the bending vibration of carbon and hydrogen bond in aliphatic groups $[25,29,30]$. Peaks at 1158,1116 , and $721 \mathrm{~cm}^{-1}$ are the result from the overlay vibrations of aliphatic ethers in triacylglycerols $[25,29,31]$. FFA levels in refined meal oils usually found at levels below $0.1 \%(\mathrm{w} / \mathrm{w})$, while FFA levels in crude oil ranging from 1$15 \%(\mathrm{w} / \mathrm{w})$. This higher levels of FFA occur due to hydrolysis of tryacylglycerols in crude oil. High levels of FFA can also occurred as a consequence of the release of lipase due to tissue damage [32].

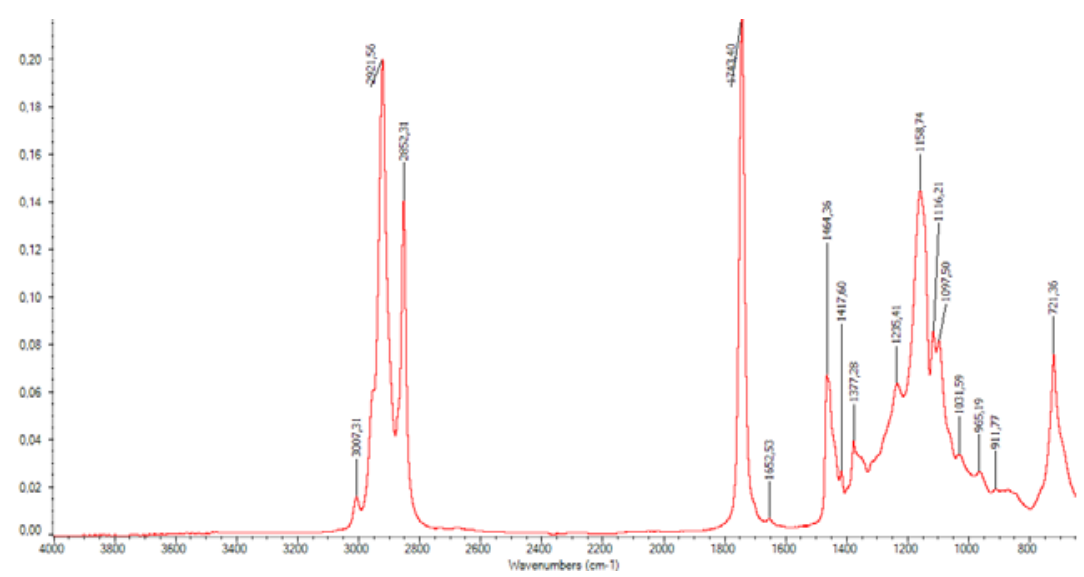

Fig. 2: ATR-FTIR spectra of $P$. hypopthalmus oil

In the present study, 7 models (normal and derivative) of each PLS and PCR were tested and investigated in terms of coefficient of determination $\left(\mathrm{R}^{2}\right)$, root mean square error of calibration (RMSEC) and root mean square error of prediction (RMSEP), to obtain the most accurate models to predict FFA. PLS is a multivariate calibration technique intended to reduce data dimensions and to find out the most relevant factors in predicting and interpreting data. By balancing the information between predictors and responses, PLS reduces the impact of many of the predictors irrelevant to the data diversity. Predictors giving high correlation are more concernsince it will be more effective for prediction. PCR also used for linear regression models, when the number of independent variables (predictors) is very large, or when interceptors are highly correlated. One of the most important 
applications of PCR is multivariate calibration, where the goal is to predict constituent concentrations based on the spectrum. The spectrum analysis can be obtained through various techniques, one of them is FTIR spectroscopy. FTIR spectra typically composed of values that reach a wide range of wave numbers, so that it consists of hundreds of components to be analyzed [33]. Different regions of wavenumber were selected and evaluated to find the suited model which give the optimum model for FFA prediction. PCR at 1.200$1.000 \mathrm{~cm}^{-1}$ with first derivative treatment was selected to predict FFA as shown in table 2 .

Table 2: The performance of PLS and PCR models for prediction of fatty acid levels in P. hypopthalmus oil.

\begin{tabular}{|c|c|c|c|c|c|c|}
\hline & Region $\left(\mathrm{cm}^{-1}\right)$ & treatment & factors & $\mathbf{R}^{2}$ & RMSEC & RMSEP \\
\hline \multirow[t]{7}{*}{ PLS } & $1425-1105$ & Normal & 1 & 0.4075 & 1.97 & 1.91 \\
\hline & $1200-1000$ & Normal & 1 & 0.4018 & 1.97 & 1.94 \\
\hline & $3100-2900$ & Normal & 1 & 0.2790 & 2.07 & 2.24 \\
\hline & $1392-1382,1439-1423,1460-1439,1765-1747$ & First derivative & 1 & 0.4198 & 1.95 & 2.16 \\
\hline & $1200-1000$ and $3100-2900$ & First derivative & 1 & 0.3090 & 2.05 & 2.43 \\
\hline & $1200-1000$ & First derivative & 3 & 0.5406 & 1.81 & 2.17 \\
\hline & $3100-2900$ & First derivative & 6 & 0.4435 & 1.93 & 3.89 \\
\hline \multirow[t]{7}{*}{ PCR } & $1425-1105$ & Normal & 10 & 0.7639 & 1.39 & 2.60 \\
\hline & $1200-1000$ & Normal & 10 & 0.9276 & 0.804 & 4.50 \\
\hline & $3100-2900$ & Normal & 6 & 0.4433 & 3.84 & 7.47 \\
\hline & $1392-1382,1439-1423,1460-1439,1765-1747$ & First derivative & 10 & 0.7246 & 1.48 & 3.24 \\
\hline & $1200-1000$ and $3100-2900$ & First derivative & 10 & 0.8967 & 0.953 & 2.26 \\
\hline & $1200-1000$ & First derivative & 10 & 0.9417 & 0.725 & 2.40 \\
\hline & $3100-2900$ & First derivative & 10 & 0.7584 & 1.40 & 2.95 \\
\hline
\end{tabular}

\section{The wavenumbers marked with bold was preferred for prediction}

As it can be seen in table 2, the PCR model at wavenumbers region of $1200-1000 \mathrm{~cm}-1$ using first derivative treatment (fig. 3) offered the highest $\mathrm{R}^{2}$ and the lowest results of RMSEC and RMSEP. These findings indicate that the PCR at $1.200-1.000 \mathrm{~cm}^{-1}$ with first derivative treatment was the most accurate among other developed models in this study. Fig. 3 shows the first derivative treatment to the spectra at $1.200-1.000 \mathrm{~cm}^{-1}$, this treatment removes baseline shifts and improves the accuracy of quantification [34].

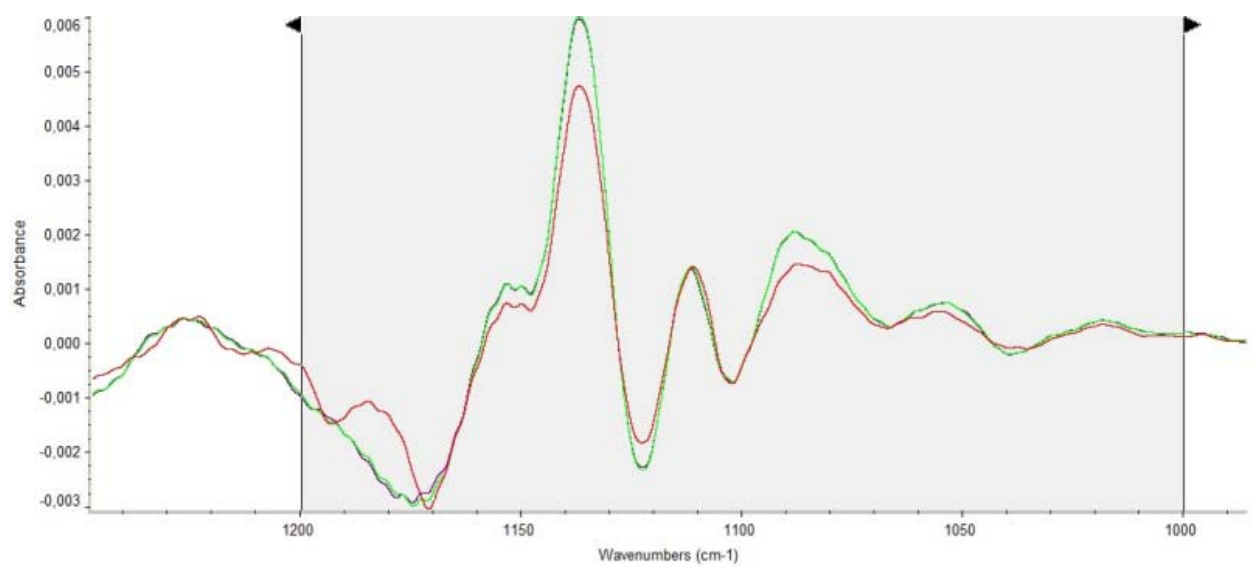

Fig. 3: First derivative spectra

The scatter plot in fig. 4 (a) showed the relationship between FFA actual and FFA calculated. The FFA actual in the $x$ values obtained from the standard titration method, whereas the FFA calculated in $y$ values given by the prediction model generated by FTIR using PCR model. The time required for FFA determination of sample by titration takes 10-20 min, while the time required for FFA determination uses
FTIR in less than three minutes. This time comparison is in line with the previous research which stated that FTIR spectroscopy indeed not time-consuming. This method was also not laborious and an easy method. Besides, FTIR spectroscopy also reduced the number of chemical solvents usually used in the standard method for FFA determination, such as ethanol and sodium hydroxide.

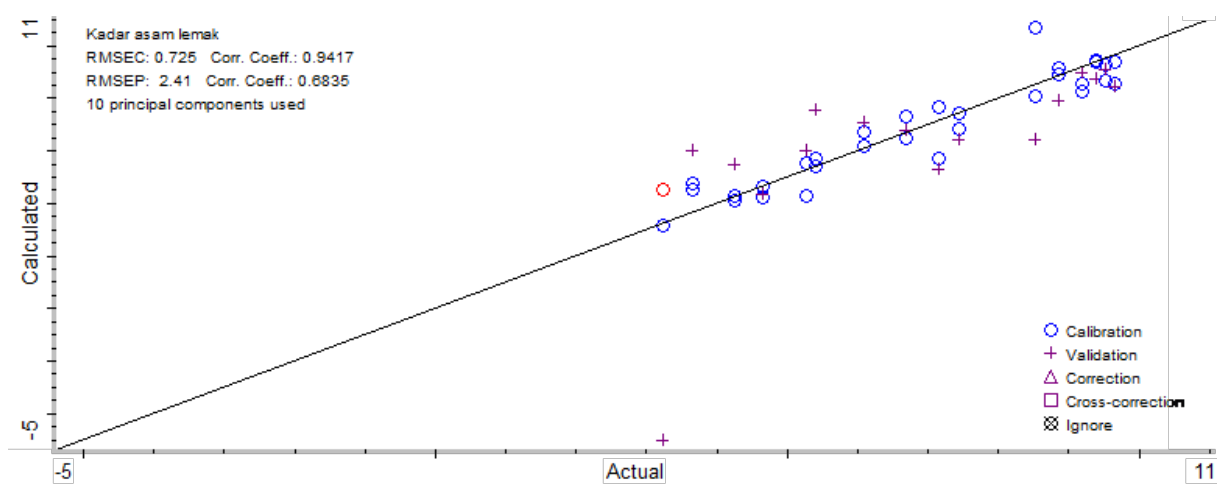

(a) 


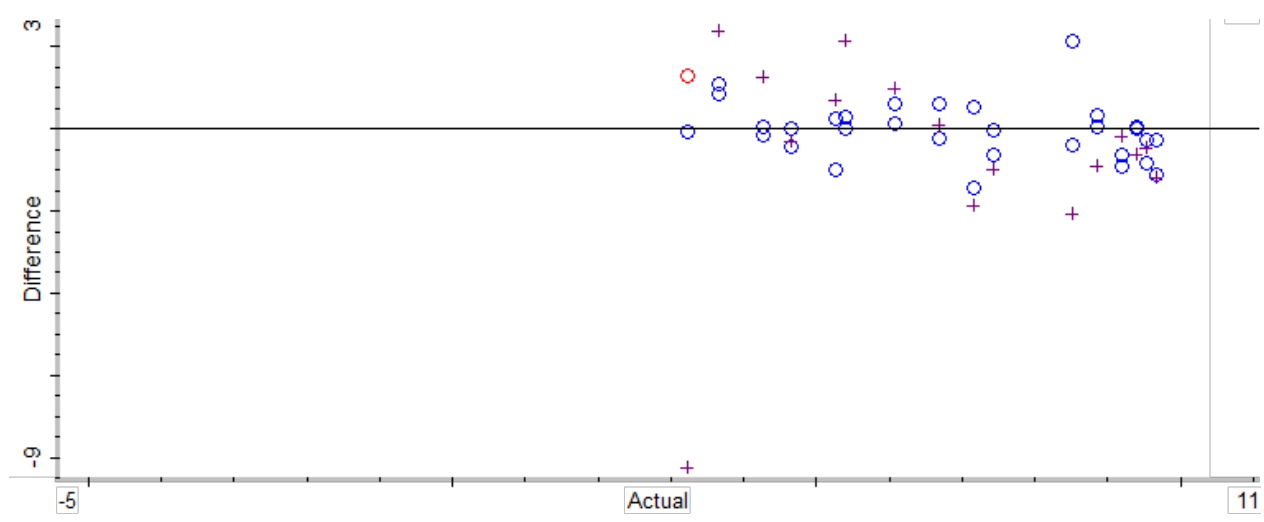

(b)

Fig. 4: a. Calibration curve from the determination of FFA by FTIR and PCR. b. Residual plot for regression analysis

At least there are two concerns regarding a developed model; the first is the prediction result by the developed model and the second is residual results generated by the developed model shown in fig. 4 (b). Residual plot aims to analyze whether a regression obtained by the model is suitable to use as a prediction model. It's clearly shown in fig. 4 (b) that the residual plots in regression represent a satisfactory distribution of residuals. It can be seen that such plots are approximately identical across the line, and normally distributed close to zero. The residual plots gave the conclusion that PCR at 1.200-1.000 $\mathrm{cm}^{-1}$ with first derivative treatment has been used as the correct and suited model for prediction of FFA in P. hypopthalmus oil.

\section{CONCLUSION}

FTIR spectroscopy combined with multivariate calibration of PCR at 1.200-1.000 $\mathrm{cm}^{-1}$ with first derivative treatment can be used as an alternative method for prediction of FFA in P. hypopthalmus oil.

\section{ACKNOWLEDGMENT}

The authors thank the Ministry of Research and Technology of The Republic of Indonesia for the Competitive Grants.

\section{AUTHORS CONTRIBUTIONS}

LA, RS, and ANP performed research activities and prepared manuscript. LA and AR designed research, analyzed data, and made critical thinking on the manuscript.

\section{CONFLICTS OF INTERESTS}

All authors have none to declare

\section{REFERENCES}

1. Thuy NT, Loc NT, Linberg JE, Ogle B. Survey of the production, processing and nutritive value of cftsh by -product meals in the Mekong Delta of Vietnam. Livestock Res Rural Dev 2007;19:1-5.

2. Hastarini E, Fardiaz D, Irianto HE, Budijanto S. Characteristics of fish oil produced from fillet processing waste of Siam (Pangasius hypopthalmus) and Jambal (Pangasius djambal) catfish. Agritech 2012;32:403-10.

3. Panagan, AT, Yohandini H, Gultom JU. Analisis kualitatif dan kuantitatif asam lemak tak jenuh omega-3 dari minyak ikan patin (Pangasius pangasius) dengan metode kromatografi gas. J Universitas Sriwijaya Sumatera Selatan 2011;14:38-42.

4. Republika e-newspaper; 2014. Available from: http://www. republika.co.id/berita/ekonomi/bisnis/14/07/15/n8qdb8wowpendapatan-dari-bisnis-ikan-patin-di-daerah-ini-tembusrp-200-m. [Last accessed on 10 Apr 2017]

5. Alberta NAA, van de Voort FR, Benjamin KS. FTIR determination of free fatty acids in fish oils intended for biodiesel production. Process Biochem 2009;44:401-5.

6. Triyasmono L, Riyanto S, Rohman A. Determination of iodine value and an acid value of red fruit oil by infrared spectroscopy and multivariate calibration. Int Food Res J 2013;20:3259-63.
7. Li H, van der Vort FR, Sedman J, Ismail AA. Rapid determination of cis and trans content, iodine value and saponification number of edible oils by fourier transform near-infrared spectroscopy. J Am Oil Chem Soc 1999;76:491-7.

8. Abdul Rohman, Liling Triyasmono, Sugeng Riyanto, Lisa Andina. Rapid determination of saponification value in red fruit oil by infrared spectroscopy and partial least square calibration. Res J Med Plant 2015;9:442-8.

9. Kampars V, Kronberga S. Iodine values estimation of vegetable oils by FTIR spectroscopy. Pol J Food Nutr Sci 2003;12:45-7.

10. Hayati IN, Che Man YB, Tan CP, Aini IN. Monitoring peroxide value in oxidized emulsions by fourier transform infrared spectroscopy. Eur J Lipid Sci Technol 2005;107:886-95.

11. Andina L, Riyanto S, Rohman A. Determination of peroxide value of red fruit oil by FTIR spectroscopy and multivariate calibration. Int Food Res J 2017;24:2312-6.

12. Guillen MD, Cabo N. Fourier transform infrared spectra data versus peroxide and anisidine values to determine oxidative stability of edible oils. Food Chem 2002;77:503-10.

13. Andina L, Riyanto S, Rohman A. Determination of anisidine value of red fruit oil under elevated temperature using FTIR spectroscopy and multivariate calibration. Int Food Res J 2014;21:2325-30.

14. Nugrahani I, Dillen N. Rapid assay development of diclofenac sodium coated tablet assay using FTIR compared to HPLC method. Int J Appl Pharm 2018;10:43-50.

15. Nugrahani I, Khalida FN. Green method for acetaminophen and ibuprofen simultaneous assay in the combination tablet using FTIR. Int J Appl Pharm 2018;10:77-83.

16. Rohman A, Che man YB. Monitoring of virgin coconut oil (VCO) adulteration with palm oil using fourier transform infrared (FTIR) spectroscopy. J Food Lipids 2009;16:618-28.

17. Farkas T, Fodor E, Kitajka K, Halver JE. Response of fish membranes to environmental temperature. Aquac Res 2001;32:645-55.

18. Hochachka PW, Somero GN. Biochemical adaptation: mechanism and process in physiological evolution. New York: Oxford University Press; 2002. p. 17-8.

19. Jobling $M$, Bendikson EA. Dietary lipids and temperature interact to influence tissue fatty acid compositions of Atlantic salmon, Salmo salar L, parr. Aquac Res 2003;34:1423-41.

20. Skalli A, Robin JH, Le Bayon N, Le Delliou H, Person-le Ruyet J. Impact of essential fatty acid deficiency and temperature on tissues' fatty acid composition of European sea bass (Dicentrarchus labrax). Aquaculture 2006;255:223-32.

21. Gunston FD. The chemistry of oils and fats. UK: Blackwell Publishing Ltd; 2004. p. 52-3.

22. Rohman A, Riyanto S, Che man YB. Characterization of red fruit (Pandanus coneideus Lam) oil. Int Food Res J 2012;19:563-7.

23. Guillen MD, Cabo N. Usefulness of the frequencies of some fourier transform infrared spectroscopic bands for evaluating the composition of edible oil mixtures. Fett Lipid 1999;101:71-6.

24. Che Man YB, Setiowaty G. Application of fourier transform infrared spectroscopic to determine free fatty acid contents in palm olein. Food Chem 1999;66:109-14. 
25. Vlachos N, Skopelitis $Y$, Psaroudaki M, Konstantinidou V, Chatzilazarou A, Tegou E. Application of fourier transforminfrared spectroscopy to edible oils. Anal Chim Acta 2006;573:459-65.

26. Che Man YB, Marina AM, Rohman A, Al-Kahtani HA, Norazura OA. FTIR spectroscopy method for analysis of palm oil adulterated with lard in pre-fried french fries. Int J Food Prop 2013;17:354-62.

27. Rohman A, Che Man YB. FTIR spectroscopy combined with chemometrics for analysis of lard in the mixtures with body fats of lamb, cow, and chicken. Int Food Res J 2010;17:519-26.

28. Pednekar PA, Raman B. The FT-IR spectrometric studies of Semecarpus anacardium Linn. F. leaf, stem powder, and extracts. Asian J Pharm Clin Res 2013;6 Suppl 1:159-98.

29. Pavia DL, Lampman GM, Kriz-jr GS. Introduction to spectroscopy: a guide for students of organic chemistry, third edition, London: Thomson Learning Inc; 2001. p. 579.
30. Kamble V, Gaikwad N. Fourier transform infrared spectroscopic studies in Embelia ribes Burm. F.: A vulnerable medicinal plant. Asian J Pharm Clin Res 2016;9 Suppl 3:41-7.

31. Guillen MD, Cabo N. Characterization of edible oils and lard by spectroscopy: the relationship between composition and frequency of concrete bands in the fingerprint region. J Am Oil Chem Soc 1997;74:1281-6

32. Hammond EW. Fatty acid/Analysis. In encyclopedia of food science and nutrition (Second Edition). Academic Press, U; 2003. p. 2311-7.

33. Miller JN, Miller JC. Statistics and chemometrics for analytical chemistry, Sixth Edition. Ashford Colour Press Ltd, Gosport, UK; 2010. p. 241-5.

34. Rohman A, Setyaningrum DL, Riyanto S. FTIR spectroscopy combined with partial least square for analysis of red fruit oil in ternary mixture system. Int J Spec 2014:1-5 http://dx.doi.org/10.1155/2014/785914. 